\title{
Modelling the population control of the domestic cat: an example from an island in Brazil
}

\author{
Lessa, ICM*. and Bergallo, $H G$. \\ Ecologia de mamíferos, Laboratório de Ecologia de Mamíferos, Departamento de Ecologia, \\ Instituto de Biologia Roberto Alcântara Gomes, Universidade do Estado do Rio de Janeiro -UERJ, \\ Rua São Francisco Xavier 524, CEP 20550-900, Rio de Janeiro, RJ, Brazil \\ *e-mail: isadoracristinam@gmail.com \\ Received June 13, 2011 - Accepted September 2, 2011 - Distributed August 31, 2012
}

(With 2 figures)

\begin{abstract}
The domestic cat is an invasive species that often causes great impacts where introduced due to its high predatory and reproductive potential, especially on islands. In this study, carried out on Ilha Grande (RJ, Brazil), we aimed to: i) estimate the population density of domestic cats, ii) calculate the number of animals preyed upon annually by domestic cats, and iii) evaluate the efficiency of methods to control the cat population. We used the Vortex program to project the population growth of domestic cats in fifty years, and simulated different scenarios of population control (without control, castration, spay and harvest). Population density of owned cats was $662 \mathrm{cats} / \mathrm{km}^{2}$. The annual predation rate was 1.97 prey animals/cat which is an average of 1497.96 prey/year. The population would only be reduced if $70 \%$ of females were spayed or removed annually. Measures to control the domestic cat population must be undertaken urgently, since uncontrolled growth of this predator has the potential to seriously impact the biodiversity of Ilha Grande.
\end{abstract}

Keywords: invasive species, Felis catus, predation rate, population density, castration simulation.

\section{Modelando o controle populacional de gato doméstico: um exemplo de uma ilha no Brasil}

\begin{abstract}
Resumo
O gato doméstico é uma espécie invasora que frequentemente causa grandes impactos onde é introduzido, em razão do seu alto potencial predatório e reprodutivo, especialmente em ilhas. Com este estudo realizado na Ilha Grande-RJ, Brasil, tivemos como objetivos: i) estimar a densidade populacional de gatos domésticos; ii) calcular o número de animais predados anualmente por gatos domésticos, e iii) estimar a eficiência de métodos para o controle da população de gatos. Nós utilizamos o programa Vortex para projetar o crescimento da população de gatos em 50 anos e simulamos diferentes cenários de controle populacional: sem controle, castração, esterilização de fêmeas e remoção de indivíduos. A densidade populacional de gatos que possuem donos foi de 662 gatos $/ \mathrm{km}^{2}$. A taxa anual de predação foi de 1,97 animais predados/gato, ou seja, uma média de 1497,96 presas/ano. A população de gatos pode ser reduzida apenas se no mínimo $70 \%$ das fêmeas forem esterilizadas ou removidas anualmente. Medidas para o controle populacional de gatos domésticos devem ser tomadas com urgência, uma vez que o crescimento descontrolado da população desse predador tem o potencial de causar graves impactos à biodiversidade da Ilha Grande.
\end{abstract}

Palavras-chave: espécie invasora, Felis catus, taxa de predação, densidade populacional, simulação de castração.

\section{Introduction}

The introduction of new species is the biggest threat to biological diversity on islands (Groombridge, 1992; Courchamp et al., 2003), being a major concern for conservation management nowadays. To stem the damage caused by invasive alien species, one of the most feasible devices is population control or eradication (Blackburn et al., 2010).

The domestic cat (Felis catus, Linnaeus, 1758) has been introduced onto several islands as an attempt to

control exotic rodents (Brikner, 2007). However, since the beginning of the 17 th century, 176 bird species have been made extinct by introduced cats, and $93 \%$ of these lived on oceanic islands (King, 1985). Cats are notoriously one of the worst predators on islands, and are considered by Lowe et al. (2000) to be one of the 100 worst exotic invasive species in the world.

Due to the restricted size of islands and the high rates of endemism, introduced species severely threaten 
insular species (Tomkins, 1985). Domestic cats are an even worse threat due to its high reproductive capacity (Courchamp et al., 2003; Bonnaud et al., 2007).

When a female cat starts its reproductive cycle, it mates for 15 days with one or more males until fertilization occurs (Gunther and Terkel, 2002). In the tropics, domestic cats can reproduce throughout the year, as long as they have access to sufficient food and habitats (Fitzwater, 1994).

According to Nogales et al. (2004), attempts to remove feral cats have been made on 48 islands all over the world. Removal has been successful on $75 \%$ of those islands, most of them smaller than $10 \mathrm{~km}^{2}$, and in the sub-Antarctic Marion Island, southern Indian Ocean, with an area of $290 \mathrm{~km}^{2}$ (Bester et al., 2002).

Eradication programmes on islands have been applied mainly to feral cats (Nogales et al., 2004), i.e. cats that have no owners and depend on environmental resources. The methods used in different eradication programmes are many, such as poisoned baits, usually rats or fishes that ingested anticoagulants such as brodifacoum (Brown, 1997; Brown et al., 1998); introduction of viral diseases such as feline panleukopenia (Van Resburg, 1987); hunting with dogs (Bester, 2002); and traps (Short and Turner, 2005).

However, such forms of control, particularly the introduction of viral diseases and prey poisoning, are not feasible in most areas in Brazil for two main reasons: the presence of other animals, including native felines in forested areas near urban areas (Pereira et al., 2001), and the rejection of these methods by residents.

No research has been undertaken so far on the effects of domestic cats in Brazil on islands. Our study was conducted on Ilha Grande, an island covered by Atlantic rainforest that supports a growing population of people and cats.

Considering the severe impacts that can be caused by domestic cats in natural environments, especially insular ones, the objectives of this study were 1) to estimate the population density of domestic cats on an island off the coast of Brazil; 2) to calculate the average number of animals preyed upon annually by domestic cats; and 3) to investigate which method of population control could reduce cat density, considering five different scenarios for projected population growth.

\section{Methods}

\subsection{Study area}

The Ilha Grande is a coastal island of $190 \mathrm{~km}^{2}$, located on the southweast coast of Rio de Janeiro state. This island comprises two important conservation units: the Parque Estadual da Ilha Grande and the Reserva Biológica da Praia do Sul (Saraça et al., 2009; Alho et al., 2002). The island has $85 \%$ coverage by a mosaic of secondary dense Atlantic rainforest with different ages (Oliveira, 2008). Our study was carried out at Vila do Abraão (23 $08^{\circ} 28.44^{\prime}$ ' S and $\left.44^{\circ} 10^{\prime} 10.05^{\prime}, \mathrm{W}\right)$, the largest urban area on this island, covering $0.37 \mathrm{~km}^{2}$ and supporting about 1800 inhabitants, according to the last census from 2006 (IBGE, 2008).

\subsection{Domestic cat population}

We carried out a survey of domestic cats in all the houses at Vila do Abraão from May to November 2008, in order to record population parameters about the cats that have owners. We applied a questionnaire to each cat's owner to find out the number of cats owned, the gender and age of the cats, whether they were neutered, and the numbers of females and kittens produced per year. These cats were registered and whenever possible, photographed.

Additionally, the density of domestic cats on the streets was estimated using the linear transect method (Buckland et al., 2001), in order to complement our surveying. We delimited five transects at Vila do Abraão, varying in length from $885 \mathrm{~m}$ to $1,147 \mathrm{~m}$. Each transect was walked four times during three periods (morning, afternoon and evening), and one of these periods was repeated randomly. The total length of transects covered was $21 \mathrm{~km}$. We used software Distance 5.0 to estimate the density of domestic cats on the streets (Laake et al., 1993). Population density was estimated by dividing the total number of individuals counted in the houses and in the streets, divided for the urban area $\left(0.37 \mathrm{~km}^{2}\right)$.

\subsection{Predation by domestic cats}

To measure which animals are preyed on by domestic cats inside the study area, we asked cat owners to retain all animals captured by their cats in a container with alcohol $(500 \mathrm{~mL})$. This methodology refers to domestic cats that often bring their prey home (Churcher and Lawton, 1987; Barratt, 1997; Baker et al., 2008). We collected prey animals every 20 days for six months, from May to November.

For accuracy of prey collected by owners, we measured the degree of interest of each participant in the project through information provided by a questionnaire applied during the visits. Values were assigned to five attributes that were assessed in the questionnaire: 1) Knowledge of the cat's owner - considering information such as name, age, whether vaccinated or castrated, and living area; 2) Clinical care - if the cat had received veterinary care, when vaccinated or castrated, and its overall health state; 3) Consistency of response - whether the same answers were given in response to questions asked more than once on different visits; 4) Presence during the visit - if the owner was present during the visits to answer the questionnaire; and 5) Interest in the research - whether the owner asked about our research, if he or she paid attention to the information received, and cared about the material received. Responses were ranked from 1 to 5 ( 1 = low interest or knowledge in the cats, $5=$ high interest and knowledge), and then used to evaluate if there was a relationship with the number of prey collected in the houses using analysis of variance.

To estimate the number of preys predated by cats we calculated the minimum daily predation rate $\left(\mathrm{P}_{\text {MIN }}\right)$ according to the formula: $\mathrm{P}_{\text {MIN }}=(\mathrm{P} / \mathrm{Ng} /$ day $)$. Where $\mathrm{P}$ is the number of prey, $\mathrm{Ng}$ is the total number of registered cats in homes and day is the total number of days elapsed during the project. Minimum daily predation was then multiplied by the estimated population size and by 365 days 
to get an idea of the predation rate of Felis catus during one year in the study area.

\subsection{Population modeling}

For population modelling we used the parameters observed at the studied cat populations of Vila do Abraão (house and street cats), to simulate population growth. We simulated the feasibility of reducing the cat population in following years with different scenarios of control methods. Analyses were carried out using Vortex 9.5 (Lacy, 1993). Vortex estimates population viability, incorporating the effects of demographic, environmental and genetic events on population dynamics (Lacy, 2000). Therefore, it is necessary to know life history parameters of the target species (Table 1). Life history parameters were obtained from the data provided in the questionnaires and confirmed by the literature (Gunther and Terkel, 2002). The software also calculated other parameters, such as the percentage of males that succeed in mating, and the average number of females that successfully find a mate each year. We simulated changes in the domestic cat population in Vila do Abraão over 50 years, using different scenarios. The scenarios below were based on methods currently used for population density control.

I. No methods of population control: In this scenario we assumed the current numbers of males and females that do not breed (15\%), thus evaluating population growth with the current neutered levels;

II. Control of reproductive males: We assumed that a minimum percentage of males do not breed, estimated for reducing population growth. Thus we simulated a method of birth control like castration;

III. Control of reproductive females: We assumed that a minimum percentage of females do not

Table 1. Population parameters used in VORTEX. Data represent values observed in the present study and confirmed in the literature. Some indicated values were estimated in each different scenario (I, II, III, IV and V).

\begin{tabular}{|c|c|c|}
\hline Parameters & Data & Reference \\
\hline \multicolumn{3}{|c|}{ Reproductive System } \\
\hline Age of first reproduction of males and females & 1 year* & $(1)$ \\
\hline Maximum reproductive age & 13 years & $(2)$ \\
\hline Maximum number of litters per year & 5 & $(1),(2)$ \\
\hline$\%$ of males per litter & 50 & $(1),(2)$ \\
\hline \multicolumn{3}{|c|}{ Reproduction rate } \\
\hline$\%$ of adult reproductive females & $\mathrm{I}, \mathrm{II}$ and $\mathrm{V}=85, \mathrm{III}$ and $\mathrm{IV}=\mathrm{SA}$ & $(1),(3)$ \\
\hline $\begin{array}{l}\text { Standard deviation }(\mathrm{Sd}) \text { in the } \% \text { of adult reproductive } \\
\text { females }\end{array}$ & 8.16 & (1) \\
\hline Average number of kittens per litter & 3 & $(1),(3)$ \\
\hline \multicolumn{3}{|c|}{ Death rate } \\
\hline $\begin{array}{l}\text { Annual Death rate of females between } 0-1 \text { year } \\
\text { old and over } 1 \text { year old }\end{array}$ & 55 and $35(\mathrm{SD}=5)$ & $(1),(2)$ \\
\hline $\begin{array}{l}\text { Annual Death rate of males between } 0-1 \text { year } \\
\text { old and over } 1 \text { year old }\end{array}$ & 45 and $45(\mathrm{SD}=5)$ & $(1),(2)$ \\
\hline \multicolumn{3}{|c|}{ Mating manipulation } \\
\hline $\begin{array}{l}\% \text { of males that are physically, psychologically and } \\
\text { physiologically able to mate }\end{array}$ & $\begin{array}{l}\mathrm{I}, \mathrm{III} \text { and } \mathrm{V}=85, \mathrm{II}=\mathrm{SA} \\
\mathrm{IV}=\mathrm{SA}, \mathrm{VI} \text { and } \mathrm{VII}=\mathrm{SA}\end{array}$ & (1) \\
\hline \multicolumn{3}{|c|}{ Population size } \\
\hline Number of individuals in the initial population & 228 & $(1)$ \\
\hline \multicolumn{3}{|c|}{ Carrying capacity } \\
\hline Carrying capacity of the study area & 1000 & (1) \\
\hline Standard deviation $(\mathrm{Sd})$ & 500 & $(1)$ \\
\hline \multicolumn{3}{|c|}{ Harvesting } \\
\hline Is the population harvested? & I, II, III and IV = no V = yes & Simulation \\
\hline Interval between harvested & $\mathrm{V}$ and $\mathrm{VI}=1$ & Simulation \\
\hline Adults females harvested & $\mathrm{V}=100$ and $\mathrm{VI}=50$ & Simulation \\
\hline Adults males harvested & $\mathrm{V}=100$ and $\mathrm{VI}=50$ & Simulation \\
\hline
\end{tabular}

SA- Value correspondent to result of Sensibility Analyses; SD- Standard deviation; (1) Present study; (2) Paragon and Vaissaire, 2001; (3) Fitzwater, 1994. *1 year is the minimal age accepted by the program. Domestic cats can have the first reproduction before 1 year. 
breed, estimated for reducing population growth. Thus we simulated a method of birth control like spaying;

IV. Control of reproductive males and females: We assumed that a minimum percentage of males and females do not breed. Both percentages estimated imply reduced population growth. Thus simulating a method of birth control like castration and spaying; and

V. Harvest of population. We assumed a minimum number of adult males and females to be removed annually from the population over five years, to reduce population growth. Thus we simulated a method of population control through removal.

For these models, we considered a closed population for all scenarios. Also, the minimum percentages and the minimum numbers of individuals were estimated, until the intrinsic growth rates decreased (Table 2). We did this by sensitivity analyses, testing different values of those parameters on Vortex.

\section{Results}

We recorded 160 cats in 66 of the 364 residences in Vila do Abraão. The overall cat-occupancy rate was therefore 0.44 cats/house. Considering only the houses with cats, the cat-occupancy is 2.42 cats/house. Fifty-three cats were sterilised, 24 males (15\% applied in the first scenario) and 29 females (18\% used as a Vortex parameter). The maximum age reported was 13 years and the mean litter size observed during the study was $3.00+2.34$ (Mean + SD).

Eighty-five cats were observed on transects. Among them, 17 had already been counted as owned cats, according to photo identification. According to Akaike's information criterion, the best-fit results were obtained with the cosine function $\left(\mathrm{AIC}_{\min }=333,01, \mathrm{AIC}_{\max }=341.93\right)$, with an effective strip width of $4.5 \mathrm{~m}$. The density estimated on the streets was 390 cats $/ \mathrm{km}^{2}$. Population density estimated in Vila do Abraão was 616 cats $/ \mathrm{km}^{2}$.

Cats brought home 93 prey items in 107 days. Invertebrates were the most common prey (54), followed by mammals (18), birds (11), reptiles (6) and amphibians (4). The minimum daily predation rate $\left(\mathrm{P}_{\mathrm{MIN}}\right)$ was 0.0054 prey animals/cat/day, representing annually 1.97 prey animals/cat. When we assumed a population with 228 individuals (registered cats plus cats observed in the transect), the $\mathrm{P}_{\text {MIN }}$ was 449.16 prey animals/year.

The ANOVA comparing the number of prey obtained with the degree of interest of the cat owner was significant $(\mathrm{F}=12.99 ; \mathrm{p}<0,001)$. With higher interest of the owner, the highest was the number of prey items obtained (Figure 1). Considering the number of prey animals obtained by the owners with the highest degrees of interest (4 and 5), the $\mathrm{P}_{\text {MIN }}$ changed from 0.0054 to 0.018 prey animals/cat/day. Hence, the predation rates estimated at Vila do Abraão varied from 1.97 to $6.57 \mathrm{prey} / \mathrm{cat} / \mathrm{year}$.

For the population growth projection in Vortex, our scenarios used a baseline population of 228 cats. Scenarios (I) and (II) presented equal growth rates $(\mathrm{r}=0.36)$ and scenarios (III) and (IV) the lower, $r=-0.061$ (Table 3). The projection in 50 years of the population growth curve

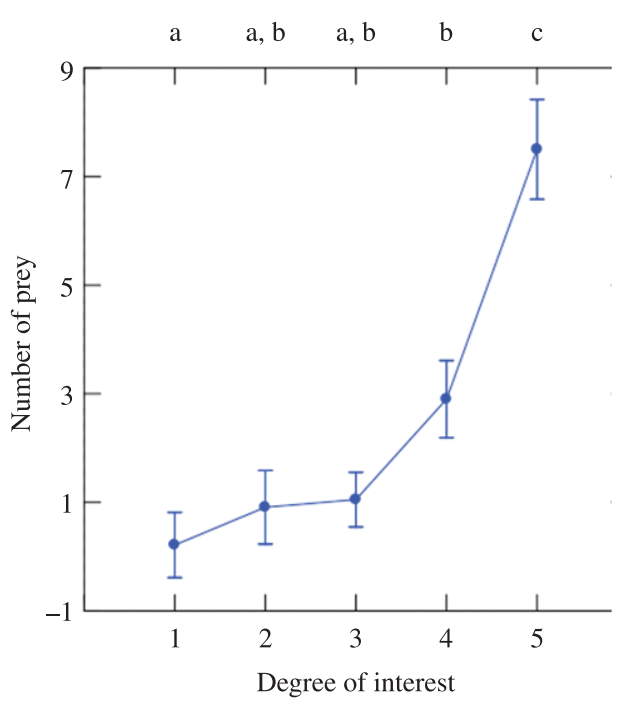

Figure 1. Numbers of prey items (mean \pm SD) returned by cats to their owners in Vila do Abraão plotted against the degree of interest shown by the owners of those cats, showing a strong positive relationship (ANOVA, F = 12,99; $\mathrm{p}<0,001)$. Different letters $(\mathrm{a}, \mathrm{b}, \mathrm{c}, \mathrm{d})$ identify means that differ between them.

Table 2. Simulations with sensibility analysis, each number represents values that can be used at a plan for population control of domestic cat.

\begin{tabular}{ccc}
\hline Sensibility analyses & Variables & Values $(\boldsymbol{\%})$ \\
\hline Scenario I & - & - \\
Scenario II & Percent of reproductive males & $80,70,50,40,20$ and $1^{* *}$ \\
Scenario III & Percent of reproductive females & $80,70,60,50,40,30 * *$ and 20, \\
Scenario IV & Percent of reproductive & 50 and 50,70 and 40,30 and \\
& males and females & $40 * *, 20$ and 40,10 and 30 \\
Scenario V & Percent of adults & 100 and 100,20 and 80,50 and \\
& males and females removed & 50,10 and 40,10 and $30 * *$ \\
\hline
\end{tabular}

\footnotetext{
$* *$ Value used at the simulation.
} 
showed that in the first two scenarios the population of cats increases until 780 cats in the first 10 years and then decreases, stabilising at around 220 individuals (Figure 2). In the first scenario the population seems to grow back after 40 years. Scenarios (III) and (IV) show the higher reduction of $99.5 \%$ and $99.8 \%$ of initial value and we observed the lowest growth rate, $r=-0.061$ (Table 3). The downward curve of the fifth scenario was similar to that of scenario IV, although there was an initial increase in the cat population (Figure 2).

Assuming population scenarios (I), (II) and (V), no modelled population was predicted to decrease in less than 7 years. Only in scenario III, IV and V, the probability of extinction, in our case control, was 99\% (Table 3).

\section{Discussion}

We estimate a high population density of domestic cats in Vila do Abraão (616 cats $\left./ \mathrm{km}^{2}\right)$, but according to Brikner (2007), it is very difficult to estimate populations of domestic cats because: (1) owners are not obliged to report their animals, (2) street cats have no population control, and (3) feral cats are rarely observed. Therefore, the best way to estimate the density of cats is combining different methods.

Although the population density estimated in the census was high, the counting of house cats, though efficient, may underestimate the population, as it does not consider un-owned street cats. We found out that $77 \%$ of the cats observed on transects did not have an owner. The

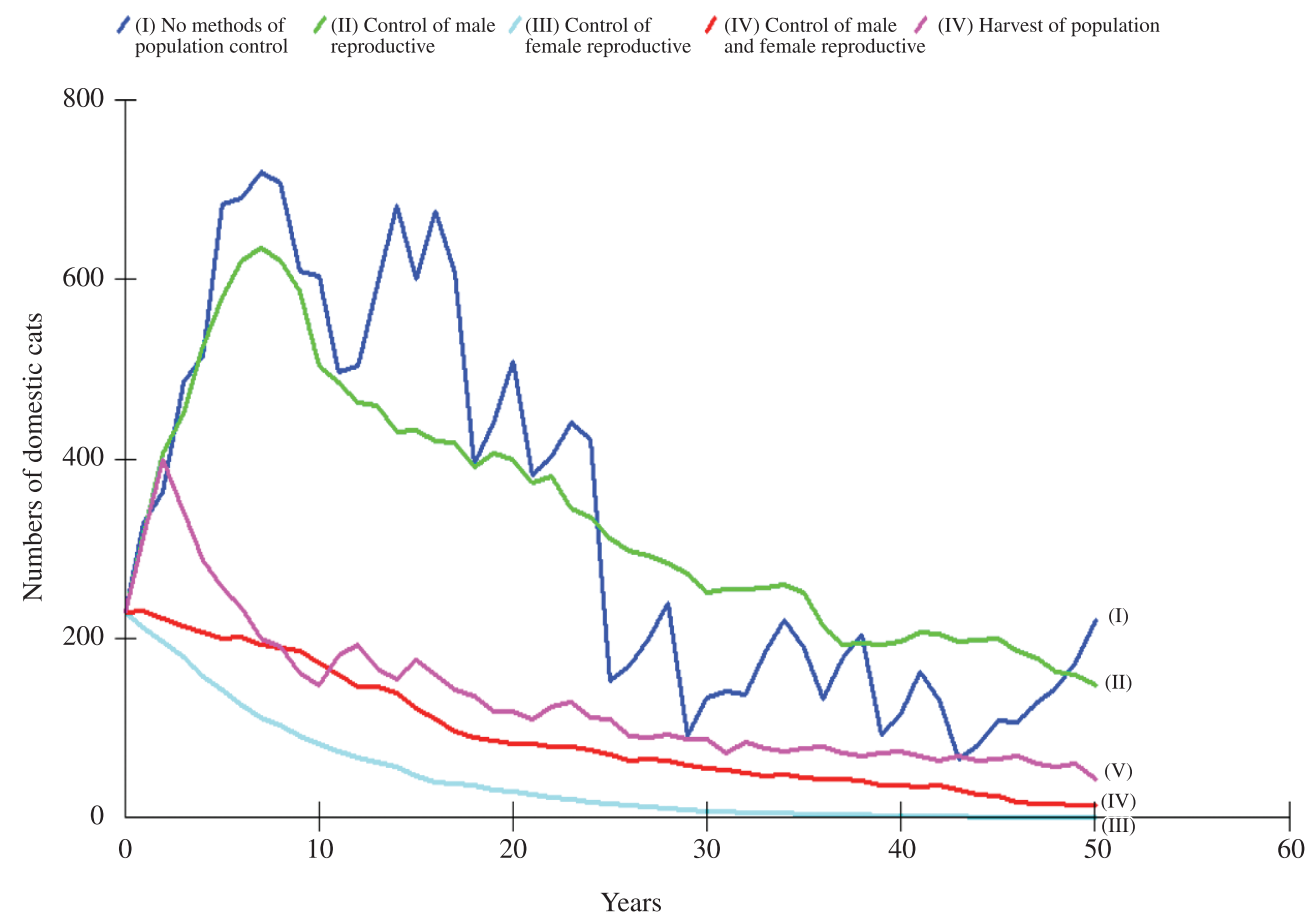

Figure 2. Projections of the cat population in Vila do Abraão calculated using Vortex software using different scenarios of population control (I to V).

Table 3. Results of modeling population viability, with the values of intrinsic growth rate (r) and the standard deviation (SD), the probability of extinction (PE), the maximum number of individuals $\left(\mathrm{N}_{\max }\right)$, and the minimum percent number of individuals by sensibility analyses $\left(\mathrm{N}_{\min }\right)$.

\begin{tabular}{ccccrc}
\hline Scenario & \multicolumn{2}{c}{$\mathbf{r}(\mathbf{S D})$} & $\mathbf{P E}$ & $\mathbf{N}_{\max }$ & $\mathbf{N}_{\min }$ \\
\hline I & 0.358 & $( \pm 0.14)$ & 0.83 & 780.61 & - \\
II & 0.36 & $( \pm 0.16)$ & 0.67 & 609.92 & 0.01 \\
III & -0.061 & $( \pm 0.06)$ & 0.99 & 1.13 & 0.3 \\
IV & -0.061 & $( \pm 0.08)$ & 0.99 & 0.33 & 0.3 \\
V & 0.025 & $( \pm 0.08)$ & 0.98 & 108.11 & 1.0 \\
\hline
\end{tabular}

Scenarios: I- No methods of population control, II- Control of male reproductive, III- Control of female reproductive, IV-Control of male and female reproductive and V- Harvested males and females. 
village is surrounded in its south, east and west sides by forest, but we did not make observations on feral cats, any interactions between urban cats and feral cats beyond the urban fringe remain unknown.

Studies have showed that population densities of cats can vary from 0.44 cats $/ \mathrm{km}^{2}$ in sub-Antarctic environments (Say et al., 2002) to 523 cats $/ \mathrm{km}^{2}$ in urban environments such as in the city of Bristol (Baker et al., 2005). In very poor or favourable conditions, according to a review of Felis catus ecology and management, densities may range even more greatly, from the equivalent of 0.03 cats $/ \mathrm{km}^{2}$ to 2800 cats $/ \mathrm{km}^{2}$ (Denny and Dickman, 2010). In the United Kingdom, the Cat Protection League estimated that there are 7.6 million cats living in British houses (Woods et al., 2003). On islands, inland areas of Marion Island sheltered only $4.93 \mathrm{cats} / \mathrm{km}^{2}$, whereas coastal areas sheltered 13.85 cats $/ \mathrm{km}^{2}$ (Van Aarde, 1979).

On 27 other islands with population control programmes for feral cats, densities varied from 0.15 to 243 individuals $/ \mathrm{km}^{2}$ (Nogales et al., 2004), which is lower than the density we observed in Vila do Abraão. But, these studies were conducted in natural areas with limited resources and a small human population. However, our results resemble those studies carried out in urban areas that reported higher densities of cats (e.g. 523 cats $/ \mathrm{km}^{2}$, Baker et al., 2008), since they receive supplementary food.

The predation rate observed in this study was underestimated by the degree of interest of owners, but it is still comparable to those found in other studies. Woods et al. (2003), conducting a five-month study in England using the same methodology, observed that some cats take to their owner over 37 prey items each year. However, this predation rate varies greatly among individuals (Churcher and Lawton, 1987). We were unable to define how many prey items each cat brought home, since on average, there were more than two cats per house ( 2.42 cats/house).

Although not measured, cats may threaten prey populations at Vila do Abraão, as predation rates based only on results from owners with a high degree of interest in the research indicated that over 1497 prey animals/year could be killed in the $0.37 \mathrm{~km}^{2}$ urban area. Clearly, because our results were dependent in part on the commitment of cat owners, it is important to select participants who will contribute reliably to such research. Beyond this, any further increases in the cat population are likely to escalate the rate of predation. If the population of cats on the island reaches 780 individuals, as expected in scenario I for example, some 5124.6 prey animals may be killed each year.

Before any conclusions can be made about possible impacts on threatened prey populations, two caveats need to be made. No matter how large the numbers of animals killed by cats may be, such estimates cannot predict the impact on prey species' populations since we do not know the information on native prey individuals.

Our population modelling suggests that scenario (III), with control of reproductive females, was the most efficient method to reduce population growth, and the scenario with harvest $(\mathrm{V})$ was effective in reducing the numbers of individuals. With others models, like control of reproductive males only (scenario II), the population was predicted to remain higher than the initial baseline. Although scenario IV had the higher expected reduction of fertility, the simulation result did not show higher control, according to the Vortex modelling. Moreover, any desired reduction would most likely occur only if the population was closed, since recruitment was not considered in our simulations.

In urban areas like Rome (Natoli et al., 2006), control is aimed at cats living in colonies, usually in parks and gardens. Eradication is feasible only with the removal of all individuals, which are taken to shelters where they are euthanised or neutered.

Gonçalves da Silva et al. (2009) carried out a modelling study on the effects of castration on large exotic mammals on islands. Using a model (Leslie's matrix type II) to simulate population decrease, they evaluated three eradication scenarios: hunting, castration, and both. They concluded that castration is an efficient method for the eradication of exotic vertebrates only if applied together with a lethal method. Courchamp and Sugihara (1999) also carried out the modelling of biological population control of a feral domestic cat, inquiring through a mathematical model that describes the effects of introducing a virus into the cat population on population dynamics of both the cat and its prey. The results suggested that eradication is possible with the introduction of Leucemia Virus in the feral cat population and is the best methodology for its extermination. However, if the cats have an owner, it is necessary to provide another methodology for population control.

Our results also suggest that male castration is not enough to eradicate the cat population in Vila do Abraão, as has been done annually by animal protection NGOs. It will be necessary to control the number of reproductive females, and spay them. Moreover, there must be at the same time a campaign to increase the awareness of residents about the damage caused by cats and an intense inspection procedure implemented on harbours to prevent the immigration of new cats to the island.

For eradication to succeed, it requires involvement of local people, researchers and government, since all the cats on the island will have to be castrated. Breeding cannot be faster than the castration campaigns and immigration of new individuals must be totally blocked or kept to near zero (Parkes, 1990; Phillips, 2010).

Thus we conclude that the population of domestic cats on Ilha Grande is high and the generated models suggest that unless $70 \%$ of females should be spayed or removed to control the population of cats. However, there should also be a simultaneous campaign aimed to educate residents about the damage caused by cats and an intense inspection process implemented at ports to prevent the immigration of new cats to the island.

Acknowledgements - We thank the residents of Vila do Abraão who collaborated with our research. INEA (Environmental State Institute) provided logistics for fieldwork. Dr. Carlos Esbérard 
made a careful reading on the text and Dr. Chris Dickman made valuable and detailed corrections to the first drafts of the manuscript. ICML thanks $\mathrm{CNPq}$ for the undergraduate scholarship and CAPES for the post-graduate scholarship. HGB thanks CNPq and Prociência/UERJ for the research fellowship. This study was supported by FAPERJ and CNPq grants.

\section{References}

ALHO, CJR., SCHNEIDER, M. and VASCONCELLOS, LA., 2002. Degree of threat to the biological diversity in the Ilha Grande State Park and guidelines for conservation. Revista Brasileira de Biologia = Brazilian Journal of Biology, vol. 62, p. 375-385. http://dx.doi.org/10.1590/S1519-69842002000300001

BAKER, PJ., BENTLEY, AJ., ANSELL, RJ and HARRIS, S., 2005. Impact of predation by domestic cats Feliscatus in an urban area. Mammal Review, vol. 35, p. 302-312. http://dx.doi. org/10.1111/j.1365-2907.2005.00071.x

BAKER, PJ., MOLONY, SE., STONE, E., CUTHILL, IE. and HARRIS, S., 2008. Cats about town: is predation by free-ranging pet cats (Feliscatus) likely to affect urban bird populations? Íbis, vol. 150, no. 1, p. 86-99. http://dx.doi.org/10.1111/j.1474919X.2008.00836.X

BARRATT, DG., 1997. Home range size, habitat utilization and movement patterns of suburban and farm cats Feliscatus. Ecography, vol. 20, p. 271-280. http://dx.doi.org/10.1111/j.1600-0587.1997. tb00371.x

BESTER, MN., BLOOMER, JP., VAN AARDE, RJ., ERASMUS, BH., VAN RENSBURG, PJJ., SKINNER, JD., HOWELL, PG. and NAUDE, TW., 2002. A review of the successful eradication of feral cats from sub-Antarctic Marion Island, Southern Indian Ocean. South African Journal of Wildlife Research, vol. 32, no. 1, p. 65-73.

BLACKBURN, TM., PETTORELLI, N., KATZNER, T., GOMPPER, ME., MOCK, K. GARNER, TWJ., ALTWEGG, R., REDPATH, S. and GORDON, IJ., 2010. Dying for conservation: eradicating invasive alien species in the face of opposition. Anime Icons, vol. 13, p. 227-228. http://dx.doi.org/10.1111/j.1469-1795.2010.00372.x

BRIKNER, I., 2007. The impact of domestic cat (Feliscatus) on wildlife welfare and conservation: a literature review. With a situation summary from Israel. Israel Journal of Ecology \& Evolution, vol. 53, no. 2, p. 129-142.

BONNAUD, E., BOURGEOIS, K., VIDAL, KY., TRANCJANT, Y. and LEGRAND, L., 2007. Feeding ecology of a feral cat population on a small Mediterranean island. Journal of Mammal, vol. 88, no. 4, p. 1074-1081. http://dx.doi.org/10.1644/06-MAMM-A-031R2.1

BROWN, KP., 1997. Impact of brodifacoum poisoning operations on South Island Robins Petroicaaustralisaustralis in New Zealand Nothofagus forest. Bird Conservation International, vol. 7, p. 399-407. http://dx.doi.org/10.1017/S0959270900001726

BROWN, KP., ALTERIO, N. and MOLLER, H., 1998. Secondary poisoning of stoats (Mustelaerminea) at low mouse (Musmusculus) abundance in a New Zealand Nothofagus forest. Wildlife Research, vol. 25, p. 419-426. http://dx.doi.org/10.1071/WR97069

BUCKLAND, ST., ANDERSON, DR., BURNHAM, KP., LAAKE, JL., BORCHERS, DL. and THOMAS, L., 2001. Introduction to Distance Sampling. Oxford: University Press. 432 p.

CHURCHER, PB. and LAWTON, JH., 1987. Predation by domestic cats in an English village. Journal of Zoology, vol. 212, p. 439-455. http://dx.doi.org/10.1111/j.1469-7998.1987.tb02915.x
COURCHAMP, F. and SUGIHARA, G., 1999. Modeling the biological control of an alien predator to protect island species from extinction. Ecological Applications, vol. 9, no. 1, p. 112-123. http://dx.doi.org/10.1890/1051-0761(1999)009[0112:MTBCO A]2.0.CO;2

COURCHAMP, F., PASCAL, M. and CHAPUIS, JL., 2003. Mammal invaders on islands, impact, control and control impact. Biological Reviews, vol. 78, p. 383-390. PMid:14558589. http:// dx.doi.org/10.1017/S1464793102006061

DENNY, EA. and DICKMAN, CR., 2010. Review of cat ecology and management strategies in Australia. Invasive Animals Cooperative Research Centre, Canberra Press. 84 p.

FITZWATER, WD., 1994. House cats (Feral), prevention and control of wildlife damage. Lincoln: Cooperative Extension Division Institute of Agriculture and Natural Resources University of Nebraska. Available from: <http://digitalcommons.unl.edu/cgi/ viewcontent.cgi?article $=1031>$.

GONÇALVES DA SILVA, A., KOLOKOTRONIS, SO. and WHARTON, D., 2009. Modeling the eradication of invasive mammals using the sterile male technique. Biological Invasions, vol. 12, no. 4, p. 1387-3547.

GROOMBRIDGE, B., 1992. Global biodiversity: status of earth living resources. London: Chapman and Hall. 594 p.

GUNTHER, I. and TERKEL, J., 2002. Regulation of free-roaming cat (Felissilvestriscatus) populations: a survey of the literature and its application to Israel. Animal Welfare, vol. 11, no. 2, p. 171-188.

Instituto Brasileiro de Geografia e Estatística - IBGE, 2008. Available from: <http://www. ibge. gov. br/home/mapa_site/ mapa_site. php \#populacao>. Access in: dez. 2010.

KING, WB., 1985. Island Birds: will the future repeat the past? Cambridge. ICBP Tech. Publ. vol. 3, p. 3-15.

LAAKE, JL., BUCKLAND, ST., ANDERSON, DR. and BURNHAM, KP., 1993. Distance User's guide v2. O. Fort Collins: Colorado Cooperative Fish and Wildlife Research Unit, Colorado State University.

LACY, RC., 1993. Vortex: A computer simulation model for Population Viability Analysis. Wildlife Research, vol. 20, p. 45-65. http://dx.doi.org/10.1071/WR9930045

,- 2000 . Structure of the VORTEX simulation model for population viability analysis. Ecological Bulletins, vol. 48, p. 191-203.

LOWE, S., BROWNE, M., BOUDJELAS, S. and DE POORTER, M., 2000. 100 of the World's Worst Invasive Alien Species a selection from the Global Invasive Species Database. Published by The Invasive Species Specialist Group - ISSG, Species Survival Commission - SSC, World Conservation Union - IUCN. 12 p.

NATOLI, E., MARAGLIANO, L., CARIOLA, G., FAINI, A., BONANNI, R., CAFAZZO, S. and FANTINI, C., 2006. Management of feral domestic cats in the urban environment of Rome (Italy). Preventative Veterinary Medicine, vol. 77, no. 3, p. 180-185. Pmid:17034887. http://dx.doi.org/10.1016/j. prevetmed.2006.06.005

NOGALES, M., MARTÍNS, A., TERSHY, BR., DONLAN CJ., VEICTH, D., PUERTA, N., WOOD, B. and ALONSO, J., 2004. A review of feral cat eradication on islands. Conservation Biology, vol. 18, no. 2, p. 310-319. http://dx.doi.org/10.1111/j.15231739.2004.00442.x

OLIVEIRA, RR., 2008. When the shifting agriculture is gone: functionality of Atlantic Coastal Forest in abandoned farming sites. 
Boletim do Museu Paraense Emílio Goeldi Ciências Humanas, vol. 3, no. 2, p. 213-226.

PARAGON, BM. and VAISSAIRE JP., 2001. Enciclopédia do gato (Royal Canin). Aniwa Publishing. 443 p.

PARKES, JP. 1990. Feral goat control in New Zealand. Biological Conservation, vol. 54, p. 335-348. http://dx.doi.org/10.1016/00063207(90)90145-F

PEREIRA, LG., TORRES, SEM., SILVA, HS. and GEISE, L., 2001. Non-volant mammals of Ilha Grande and adjacent areas in southern Rio de Janeiro state, Brazil. Boletim do Museu Nacional. Nova Série Zoologia, vol. 459, p. 1-15.

PHILLIPS, RA., 2010. Eradications of invasive mammals from islands: why, where, how and what next? Emu, vol. 110, no. 4, p. 1-7. http://dx.doi.org/10.1071/MUv110n4_ED

SARAÇA, CES., RAHY, IS., SANTOS MA., COSTA, MB., ALENCAR, RS. and PERES, WR., 2009. A propósito de uma nova regionalização para o Estado do Rio de Janeiro. In BERGALLO, HG., FIDALGO, ECC., ROCHA, CFD., UZÊDA, MC., COSTA, MB., ALVES, MAS., VAN SLUYS, M., SANTOS, MA., COSTA., TCC and COZZOLINO, ACR. Estratégias e ações para a conservação da biodiversidade no Estado do Rio de Janeiro. Rio de Janeiro: Instituto Biomas. p. 33-40.
SAY, L., GAILLARD, J-M. and PONTIER, D., 2002. Spatio-temporal variation in cat population Annual density in a sub-Antarctic environment. Polar Biology, vol. 25, p. 90-95.

SHORT, J. and TURNER, B., 2005. Control of feral cats for nature conservation. IV. Population dynamics and morphological attributes of feral cats at Shark Bay, Western Australia. Wildlife Research, vol 32, p. 489-501. http://dx.doi.org/10.1071/WR04102

TOMKINS, RJ., 1985. Breeding success and mortality of darkrumped petrels in the Galapagos and control of their predators. Conservation of Island Birds, vol. 3, p. 159-175.

VAN AARDE, RJ., 1979. Distribution and density of the feral house cat Feliscatus on Marion Island. South African Journal of Antarctic Research, vol. 9, p. 14-19.

VAN RESBURG, PJJ., SKINNER, JD. and VAN AARDE, RJ., 1987. Effects of feline panleucopaenia on the population charecteries of feral cat on Marion Island. Journal of Applied Ecology, vol. 24, p. 63-73. http://dx.doi.org/10.2307/2403787

WOODS, M., McDONALD, RA. and HARRIS, S., 2003. Predation of wildlife by domestic cats Feliscatusin Great Britain. Mammal Review., vol. 33, p. 174-188. http://dx.doi.org/10.1046/j.13652907.2003.00017.x 